\title{
IDENTIFIKASI GENOTIP CTX-M PADA Escherichia coli PENGHASIL EXTENDED SPECTRUM BETA LACTAMASE (ESBL) YANG RESISTEN PADA CEPHALOSPORIN GENERASI III DI RSUP WAHIDIN SUDIROHUSODO MAKASSAR
}

\author{
Agus Sangka Pratama ${ }^{1,2}$, M. Natsir Djide ${ }^{1}$, M. Nasrum Massi ${ }^{3}$ \\ ${ }^{1}$ Fakultas Farmasi, Universitas Hasanuddin, Makassar \\ ${ }^{2} J u r u s a n$ Farmasi, Fakultas MIPA, Universitas Islam, Makassar \\ ${ }^{3}$ Departemen Mikrobiologi, Fakultas Kedokteran, Universitas Hasanuddin, Makassar
}

Kata Kunci :

Antibiotika,

Sefalosporin generasi

III, Escherichia coli,

ESBL, CTX-M

\begin{abstract}
ABSTRAK
Penelitian ini bertujuan untuk mengetahui untuk mendaptkan gambaran tentang prevalensi kejadian Escherichia coli penghasil ESBL yang resisten terhadap cephalosporin generasi III pada pasien RSUP Dr. Wahidin Sudirohusodo Makassar dan prevalensi genotif CTX-M Escherichia coli penghasil ESBL yang resisten terhadap cephalosporin generasi III pada pasien RSUP Dr. Wahidin Sudirohusodo Makassar. Penelitian dilaksanakan diruang perawatab rawat inap, ruang ICU, ruang HCU, ruang PICU, ruang IGD anak, Infection Center, laboratorium patologi klinik RSUP Dr. Wahidin Sudirohusodo dan laboratorium mikrobiologi klinik RSP Universitas Hasanuddin Makassar periode Juni 2018 - Agustus 2018. Penelitian ini menggunakan desain eksperimental laboratorium dengan teknik pengambilan sampel secara consecutive sampling. Bakteri Escherichia coli diisolasi dari 50 pasien. Pengujian dilakukan meliputi uji sensitivitas antibiotika dengan mengunakan metode difusi agar Kirby-bauer dan vitek 2 compact, uji deteksi ESBL dengan metode Double Disc Synergy Test (DDST), Phenotypic Confirmatory Test dan Uji genotip CTX-M Polymerase Chain Reaction (PCR). Hasil penelitian menunjukkan uji sensitivitas antibiotika pada 50 sampel klinik (Urin, Sputum, Darah, Feses, Pus dan Jaringan) yang diuji terhadap antibiotika golongan sefalosporin generasi III yang telah mengalami resistensi sebesar 40 isolat (80\%) baik pada Ceftriaxone, Cefotaxime dan Ceftazidine. Pada uji fenotip dengan metode DDST dan Vitek 2 compact ditemukan 40 sampel (80\%) positif ESBL pada Antibiotika Cefotaxime+As.Klavulanat (30 ug/10 ųg ) maupun Ceftazidine+As.Klavulanat (30 ųg/10 ųg ). Pada uji genotip CTX-M di temukan 41 sampel (82\%) memiliki gen CTX-M penghasil ESBL
\end{abstract}

\section{PENDAHULUAN}

E. coli merupakan famili Enterobacteriaceae dengan habitat alami dalam saluran pencernaan manusia maupun hewan E. coli pertama kali diisolasi oleh Theodor Escherich dari tinja seorang anak kecil pada tahun 1885. Bakteri ini berbentuk batang, berukuran 0,4-0,7 x 1,0-3,0 $\mu \mathrm{m}$, termasuk gram negatif, dapat hidup soliter maupun berkelompok, umumnya motil, tidak membentuk spora, serta fakultatif anaerob (1). Escherichia coli memiliki kemampuan untuk melakukan transfer DNA melalui proses konjugasi, transduksi ataupun transformasi materi genetik dengan menyebar secara horizontal pada populasi yang sesuai (2).

Resistensi bakteri terhadap antibiotika merupakan masalah yang sangat serius dalam dunia kesehatan. Penggunaan antibiotik secara irrasional merupakan salah satu penyebab suatu antibiotik kehilangan kemampuannya dalam melawan bakteri Eschericia coli sehingga infeksi/penyakit tidak dapat terobati. Kejadian serta penyebaran resistensi bakteri lebih sering terjadi sehingga menyulitkan tatalaksana penyakit terkhusus infeksi ringan maupun berat. Salah satu mekanisme resistensi bakteri gram negatif dari famili enterobacteriaeae adalah produksi extended-spectrum beta lactamase (ESBL) (3).

Resistensi ini disebabkan akuisisi plasmid yang mengandung gen yang mengkode enzim extended-spectrum beta lactamase (ESBL), terutama diproduksi oleh Eschericia coli. Produksi extended-spectrum beta lactamase (ESBL) sangat penting untuk mengetahui mekanisme resistensi anti mikroba Eschericia coli (E. coli), serta enzim tersebut dapat menghidrolisis penisilin, sefalosporin dan antibiotik amida monosiklik, namun aktivitasnya biasanya dihambat oleh inhibitor beta-laktamase, seperti sulbaktam, asam klavulanat dan tazobaktam $(3,4)$.

Extended-spectrum beta laktamase (ESBL) adalah kelompok enzim beta-laktamase yang terdapat di dalam plasmid bakteri yang mampu menghidrolisis antibiotik golongan penicillin, cephalosporin generasi ketiga (cefotaxime, ceftriaxone dan ceftazidime) dan golongan monobactam (aztreonam) sehingga menyebabkan resistensi antibiotik tersebut pada bakteri penghasil ESBL. Enzim ini adalah TEM, SHV, CTX$\mathrm{M}$ dan OXA. Dalam beberapa tahun terakhir, inaktivatif beta-laktamase TEM dan SHV telah dilaporkan, dan kebanyakan dari mereka memiliki Enzim CTX-M. Bakteri penghasil ESBL dihambat oleh $\beta$-lactamase inhibitor (mis : asam klavulanat) dan tidak terpengaruh oleh antibiotik golongan cephamycins (mis : cefoxitin dan cefmetazole) dan carbapenem (mis : meropenem dan imipenem); serta menunjukkan sensitifitas yang bervariasi terhadap antibiotik golongan aminoglikosida, fluoroquinolon dan trimethoprimsulfamethoxazole $(5,6,7)$ 
Enzim CTX-M telah sering ditemukan di Escherichia coli dan Klebsiella, tapi itu juga telah dilaporkan pada spesies Enterobacteriaceae lainnya (8). Umumnya, plasmid bertanggung jawab untuk pengembangan gen beta laktamase di antara yang serupa atau berbeda Strain Enterobacteriaceae. Beberapa strain Enterobacteriaceae menghasilkan beta-laktamase yang dikodekan oleh kromosom dan itu bisa menyebabkan resistensi antibiotik $(3,9)$

Studi telah menunjukkan bahwa lebih dari 60 jenis CTX-M enzim telah diidentifikasi. Enzim ini dikategorikan menjadi lima kelompok utama berdasarkan variasi asam amino. Dibandingkan dengan TEM dan SHV beta lactamases, CTX-M memiliki efek yang lebih berbahaya pada sefotaksim dan ceftriaxone dari pada ceftazidime Enzim CTX-M dihambat dengan beta-laktamase, seperti asam klavulanat, sulbaktam, dan tazobaktam (10)

Pedeteksian yang dapat dilakukan untuk mendiagnosa ESBL yang direkomendasikan oleh Clinical and Laboratory Standards Institute (CLSI) adalah Metode pendeteksian dapat dibagi menjadi deteksi fenotipik (tes skreening dan konfirmasi), Metode automatik dan metode genotipik. dimana tes skrining dan tes konfirmasi ESBL $(11,12)$. Jika hasil tes skrining mengindikasikan adanya produksi ESBL, maka perlu dilakukan tes konfirmasi untuk menegakkan diagnosis. Clinical and Laboratory Standards Institute telah mengembangkan skrining uji disk diffusion dan broth microdilution dengan menggunakan agen antimikroba. Deteksi konfirmasi fenotip pada isolat yang berpotensial menghasilkan ESBL. Tes ini harus menggunakan ceftazidime dan kombinasi ceftazidime-asam klavulanat serta cefotaxime dan kombinasi cefotaxime-asam klavulanat (13)

Metode automatic menggunakan vitek ESBL card, MicroScan panel dan BD Phoenix Automated Microbiology System. Metode lainnya yang dapat digunakan untuk mendeteksi ESBL yaitu cephalosporin/clavulanate combination disks pada agar Iso-Sensitest, double-disk diffusion test, agar supplemented with clavulanat, disk replacement method dan three-dimensional test (5). Tipe ESBL dapat diketahui melalui pemeriksaan genotif (molekuler) dengan PCR. Selain itu, deteksi molekular juga dapat membantu menentukan breakpoint yang tepat (12). Metode molekuler termudah dan paling umum digunakan untuk mendeteksi keberadaan genlaktamase yang termasuk dalam famili enzim adalah Polimerase Chain Reaction (PCR) dengan primer oligonukleotida yang spesifik untuk gen-lactamase.

Oleh karena itu, penelitian ini bertujuan mengetahui prevalensi kejadian Escherichia coli penghasil ESBL yang resisten dan prevalensi genotip CTX-M terhadap sefalosporin generasi III pada pasien infeksi di RSUP Dr. Wahidin Sudirohusodo pada periode Juni - Agustus 2018.

\section{METODE PENELITIAN}

\section{Alat dan Bahan}

Alat-alat yang digunakan dalam penelitian ini Autoklaf, bunsen, BSC Tipell, cawan petri, cetakan agarosa, erlenmeyer, Gel DOC, Handscoon, hot plate, inkubator, jarum ose, kamera digital, Laminar air flow, Lemari pendingin, Mesin elektroforesis mikropipet, mikrotube, mikrosentrifuse, oven, Polymerase chain reaction (PCR), $\mathrm{pH}$ meter, pipet serologi, sentrifuge, mesin shaker, tabung ependorf, tabung uji, termometer, timbangan analitik, tips, UV transiluminator, vortex, waterbath, VITEK 2 Compact ${ }^{\circledR}$, Vorteks dan benda gelas lainnya.

Agarose, Buffer TEA, DNA leader / marker (100 bp) Etanol, Etidium bromide, $\mathrm{H}_{2} \mathrm{O}_{2}$, Kit kappa hot star Taq DNA polymerase, Kit DNA Purification, loading dey, MacConkey agar, Muller Hinton agar, Natrium clorida (NaCl) 9\% dan paper disk antibiotika (Ceftazime, Cefotaksime, Ceftriaxone, Cefotaksim + asam klavulanat, Ceftazidime + asam klavulanat) dan Primer PCR

\section{Prosedur Kerja}

\section{Isolasi dan Identifikasi}

Isolasi bakteri dalam specimen urin, sputum, pus, darah, feses dan jaringan dilakukan dengan metode gores pada medium MacConkey Agar dan di inkubasi selama 24 pada suhu 370C. setelah masa inkubasi diamati koloni bakteri yang terbentuk. Positif Escherichia coli bila bentuk koloni bulat, permukaan meninggi, licin dan putih buram. Uji identifikasi, koloni yang tumbuh pada medium disuspensikan dengan larutan $\mathrm{NaCl}$ yang dibandingkan dengan 0,5 McFarland lalu diinjeksikan sebanyak 145 ųl kedalam vitek 2 compact. Untuk identifikasi bakteri Escherichia coli digunakan kartu GN pada alat vitek 2 compact.

Phenotypic Confirmatory Test dengan menggunakan Vitek 2 Compact

Phenotypic confirmatory test pada uji bakteri yang menghasilkan Extended-Spectrum-Beta-Lactamase (ESBL) menggunakan kartu AST pada mesin VITEK 2 Compact ${ }^{\circledR}$. Tabung suspensi bakteri dan kartu VITEK 2 AST dimasukkan ke rak khusus (cassette). Rak yang berisi suspensi bakteri dan kartu dimasukkan ke vacuum chamber station. Suspensi bakteri dipindahkan ke sumuran oleh alat. Tabung transfer dipotong secara otomatis. Kartu dipindahkan ke ruang inkubator setelah 15 menit, setelah diinkubasi akan dianalisis secara otomatis. Hasil dianalisis secara automatis oleh system dan diinterpretasikan sebagai sensitif, intermediate dan resisten (14).

Phenotypic Confirmatory Test dengan menggunakan metode Double Disc Synergy Test (DDST)

Uji pendahululahan bakteri yang menghasilkan Extended Spectrum Beta Lactamase (ESBL)

Isolat Escherichia coli yang telah di kumpulkan di uji dengan metode difusi cakram berdasarkan panduan Clinical and Laboratory Standards Institute (CLSI), dengan cakram yang mengandung antibiotika (screening test) pada medium Muller-Hinton Agar. Antibiotika yang digunakan adalah Sefalosporin generasi ketiga, Cefotaxime (CTX; 30 ug), Ceftazidine (CAZ; 30 ugg) dan Ceftriaxone (CTR; 30 ųg). Uji ini dilakukan dengan preparasi suspensi bakteri standar yang setara dengan 0.5 McFarland dan diinokulasikan pada medium Mueller Hinton agar dan cakram kertas antibiotika diletakkan di atas lempengan medium dengan jarak yang seragam. Lempengan agar tersebut lalu diinkubasikan selama 24 jam pada suhu $37^{\circ} \mathrm{C}$. Diameter zona hambatan pertumbuhan diukur dan dibandingkan dengan nilai standar. Hasil positif apabila zona hambat ceftazidime $\leq 22 \mathrm{~mm}$, cefotaxime $\leq 27 \mathrm{~mm}$, dan ceftriaxone $\leq 25 \mathrm{~mm}$.

\section{Uji Konfirmasi}

Uji konformasi (Phenotypic Confirmatory Test) dilakukan dengan metode difusi agar menggunakan medium MullerHinton Agar yang telah ditanami bakteri uji Escherichia coli. Cakram-cakram kertas yang mengandung ceftazidime dan ceftazidime / asam klavulanat $(30 / 10 \mu \mathrm{g})$, dan cefotaxime dan cefotaxime / asam klavulanat (30/10 $\mu \mathrm{g})$ diletakkan dengan jarak $15 \mathrm{~mm}$ dari tengah lempengan agar Mueller Hinton, Lempengan medium diinkubasi selama 24 jam dengan suhu $37^{\circ} \mathrm{C}$. Hasil positif dari uji tersebut didefinisikan apabila terjadi peningkatan diameter zona hambat $>5 \mathrm{~mm}$ dibandingkan dengan cakram kertas tanpa asam klavulanat. 
Amplifikasi Gen CTX-M dengan Polymerase chain reaction (PCR)

\section{Isolasi DNA}

Isolat bakteri Escherichia coli positif ESBL yang telah dikultur dalam medium MacConkey Agar selama 24 jam pada suhu 370C dibuat Suspensi didalam tabung ependorf, sentrifuge selama 5 menit dengan kecepatan $3000 \mathrm{rpm}$. buang supernatant dan tambahkan 200 ul PBS, tambahkan 20 ul Proteinase K mix. Tambahkan 200 ul GSB Buffer vortex, inkubasi pada suhu $60{ }^{\circ} \mathrm{C}$ selama 20 menit dimana tiap 5 menit divortex. Tambahkan 200 ul Ethanol vortex selama 10 detik. Masukkan kedalam GS Column dalam 2 ml collection Tube. Sentrifuge $16.000 \mathrm{rpm}$ selam 1 menit buang cairan pada collection tube. Tambahkan 400 ul W1 Buffer, Sentrifuge 16.000 rpm selam 30 detik. Buang cairan pada collection tube, Tambahkan 600 ul Wash Buffer Sentrifuge $16.000 \mathrm{rpm}$ selam 30 detik. Ganti collection tube dengan yang baru, sentrifuge dengan kecepatan 16.000 rpm selam 3 menit. Pindahkan GS Column ke tabung ependorf steril. Tambahkan 100 ul Elution Buffer yang sebelumnya telah dipanaskan. sentrifuge dengan kecepatan 16.000 rpm selam 30 detik. Buang GS column cairan yang terdapat pada tabung ependorf merupakan DNA produk yang siap untuk di PCR.

\section{Amplifikasi PCR}

DNA yang digunakan sebagai Template sebanyak 5,0 ul. Primer yang digunakan yakni U1 : ATG TGC AGC ACC AGT AAA GTG ATG GC dan U2 : TGG GTA AAG TAA GTG ACC AGA ATC AGC GG. Campuran untuk reaksi PCR dengan volume 25 $\mu \mathrm{l}$ yang terdiri dari $12,5 \mu \mathrm{l}$ Go Taq master mix, $0,5 \mu \mathrm{l}$ masingmasing primer, Nuclesa free water $6,5 \mu \mathrm{l}$ dan $5 \mu \mathrm{l}$ DNA template. Kondisi PCR yang digunakan yakni denaturasi awal pada suhu $95^{\circ} \mathrm{C}$ selama 15 detik kemudian diikuti dengan 35 siklus yang terdiri dari $94^{\circ} \mathrm{C}$ selama 30 detik (denaturasi), $61^{\circ} \mathrm{C}$ selama 40 detik (annealing) dan $72^{\circ} \mathrm{C}$ selama 2 menit (ekstensi) dan diiukuti dengan ekstensi akhir pada suhu $72^{\circ} \mathrm{C}$ selama 2 menit. Hasil amplifikasi PCR kemudian dilakukan visualisasi dengan menggunakan metode elektroforesis.

\section{Visualisasi produk PCR dan analisis data}

Produk hasil PCR divisualisasikan dalam agarose $2 \%$. Sebanyak $8 \mu$ l produk PCR dicampur diatas parafilm dan ditambahkan $2 \mu \mathrm{l}$ blue juice loading dye (tanpa marker) kemudian direndam dalam larutan Ethium Bromida selama 10 menit di tempat gelap. Amati produk PCR yang terbentuk dengan UV Transilluminator dengan panjang gelombang 360 $\mathrm{nm}$. Data yang terkumpul kemudian dianalisis secara deskriptif, dimana hasil positif apabila pita sejajar dengan pita kontrol positif (593 bp). Kontrol negatif (N) yang digunakan adalah aquadest steril. Marker (M) yang digunakan merupakan DNA ladder sebesar 1000 bp.

\section{HASIL DAN PEMBAHASAN}

Penelitian ini telah dilakukan di RSUP Dr. Wahidin Sudirohusodo Makassar tepatnya diruang perawatan Lontara, ruang perawatan palem, intensive care unit (ICU), High care unit (HCU), pediatric intensive care unit (PICU), poli bedah urologi, instalasi gawat darurat anak, Infection Center, laboratorium patologi klinik Rumah Sakit wahidin Sudirohusodo Makassar dan laboratorium mikrobiologi klinik Rumah Sakit Universitas Hasanuddin Makassar. Pengambilan data penelitian dan pengujian laboratorium dilakukan pada pasien dengan diagnosa penyakit infeksi yang dirawat selama periode Juni - Agustus 2018. berdasarkan hasil pemeriksaan laboratorium berupa nilai WBC (white blood cell), nilai neutrophil, nilai limfosit, monosit, LED (Laju endap darah), PCT (procalcitonin) yang diatas nilai normal, hasil pemeriksaan bakteri penyebab infeksi dari isolate yang menunjukkan Eschericia coli satu-satunya bakteri penyebab infeksinya tanpa kontaminasi bakteri penyebab infeksi lainnya serta hasil uji resistensi antibiotik sefalosporin generasi III. sebagai Subjek penelitian yang memenuhi kriteria inklusi yaitu sebanyak 40 isolat pasien yang positif penghasil ESBL dari 50 isolat pasien yang terinfeksi bakteri Eschericia coli.

Berdasarkan karakteristik pasien, jenis penyakit yang terdiagnosa dari pasien yang juga sebagai sumber isolate bakteri Eschericia coli terbesar adalah infeksi saluran kemih sebanyak 27 pasien dengan presentase 54\%. Menurut Karowsky, Eschericia coli merupakan pathogen utama infeksi pada pasien rawat jalan maupun rawat inap dimana sekitar 85\% penyebab utama ISK (infeksi saluran kemih) dan sekitar $50 \%$ menyebabkan infeksi nosokomial di masyarakat ${ }^{15}$. Eschericia coli berperan dalam beberapa kejadian infeksi seperti infeksi saluran kemih, infeksi aliran darah, infeksi saluran cerna dan Meningitis di Indonesia $(16,17)$.

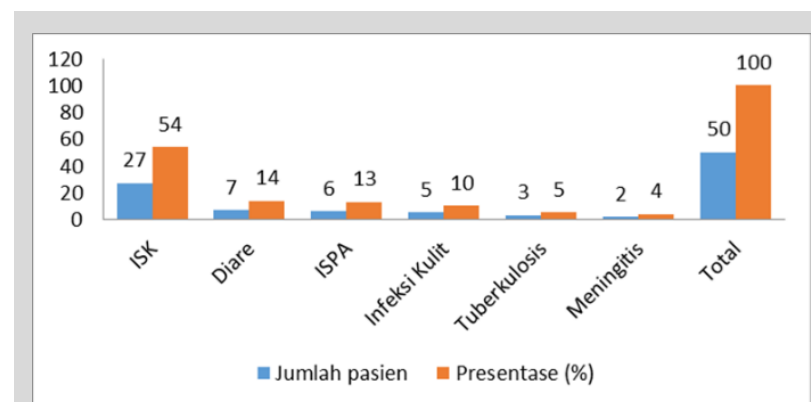

Gambar 1. Grafik diagnosa penyakit pada pasien infeksi di RSUP Dr Wahidin Sudirohusodo

Jenis antibiotika yang diberikan kepada pasien di ruangan palem, lontara, ICU, HCU, PICU, Poli bedah urologi, IGD anak dan Infection center di RSUP wahidin sudirohusodo Makassar terdiri golongan sefalosporin, penicillin, carbapenem, aminoglikosida, antiturbecular, flouroquinolon, makrolida dan antibiotika golongan lain.

Identifikasi bakteri Eschericia coli dengan vitek 2 compact diperoleh hasil tingkat kekeruhan berada pad kisaran 93\% 99\% dengan probabilitas very good. Probabilitas vitek 2 compact untuk range $96 \%-99 \%$ dinyatakan sebagai excellent, 93\% - 95\% dinyatakan very good. 89\%- 92\% dinyatakan good, 85\%- 88\% dinyatakan acceptable dan keberadaannya dua sampai tiga taxa yang memiliki pola sama dinyatakan sebagai low discmrimination $(14,18)$.

Uji sensitivitas antibiotik terhadap bakteri Eschericia coli dengan menggunakan antibiotik sefalosporin generasi III (ceftriaxone, cefotaxime dan ceftazidine), dimana 40 isolat $(80 \%)$ telah resisten terhadap antibiotik sefalosporin generasi III. Pada penelitian ini, ceftriaxone, ceftazidine dan cefotaxime mengalami resistensi yang cukup tinggi. temuan World Health Organization dan Kemenkes RI 40-62\% penggunaan antibiotik yang tidak tepat pada pasien yang tidak memerlukan antibiotik serta temuan 30\% - 80\% penggunaan antibiotik di rumah sakit tidak didasari oleh indikasi terjadi infeksi pada pasien. Penggunaan antibiotik yang tidak rasional dan tidak tepat inilah yang menimbulkan antibiotik menjadi kurang efektif serta meningkatkan resiko resistensi bakteri terhadap antibiotik $(19,20)$.

Pada uji konfirmasi fenotip ESBL menggunakan metode double disk Synergy Test (DDST) dengan disk Ceftazidime (30 $\mu \mathrm{g})$, ceftazidime + asam clavulanat $(30 / 10 \mu \mathrm{g})$, cefotaxime $(30 \mu \mathrm{g})$, cefotaxime + asam klavulanat $(30 / 10 \mu \mathrm{g})$, diperoleh hasil sebanyak 40 isolat positif penghasil ESBL. Penelitian kuntaman di tiga rumah sakit di malang, Surabaya dan semarang, dari 128 isolat $E$. coli positif penghasil ESBL yang di uji sensitivitas terhadap antibiotik sefalosporin generasi III dimana 96,88 (124 isolat) yang masih telah terhadap ceftriaxone, Cefotaxime dan ceftazidine (20). Mekanisme 
resistensi antibiotika golongan beta lactam, yaitu enzimenzim beta lactamase dapat menghidrolisis struktur cincin beta lactam sehingga antibiotik beta lactam menjadi tidak aktif, mekanisme yang lain adalah antibiotik beta lactam tidak mampu untuk mencapai tempat kerjanya atau perubahan dalam PBP yang menjadi targetnya, serta Eschericia coli mempunyai kemampuan untuk menyebar dengan mudah di antara manusia dan dapat memperoleh materi genetik melalui transfer gen horizontal yang dimediasi oleh plasmid dan transposon (22-24).

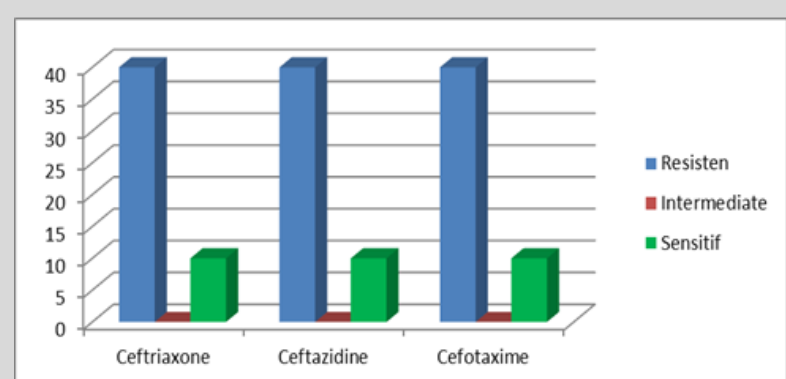

Gambar 2. Grafik kejadian resistensi antibiotik pada pasien infeksi di RSUP Dr. Wahidin Sudirohusodo

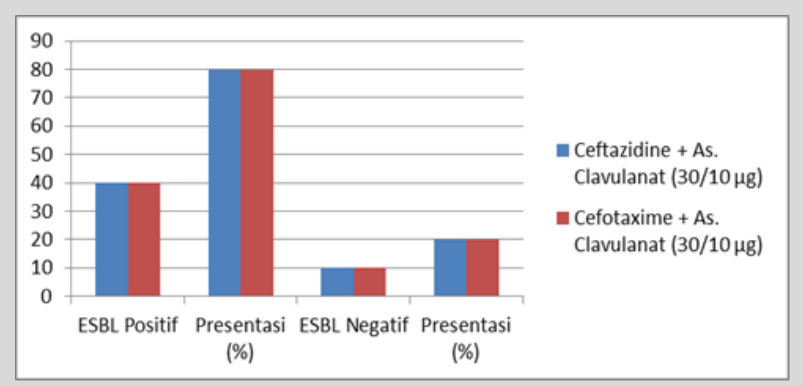

Gambar 3. Grafik Frekuensi Strain Penghasil ESBL E. coli terhadap Antibiotik Sefalosporin Generasi III pada pasien infeksi di RSUP Dr. Wahidin Sudirohusodo

Pada uji genotip CTX-M ESBL pada isolat Eschericia coli mengunakan (PCR) untuk amplifikasi DNA sedangkan untuk visualisasi produk PCR menggunakan elektroforesis gel agarose. Diperoleh hasil, sebanyak 41 isolat (82\%) positif memiliki gen CTX-M ESBL. Hal ini juga sesuai dengan beberapa penelitian yang di Indonesia, di beberapa rumah sakit di Surabaya dari 73 isolat Escherichia coli positif penghasil ESBL 94,5\% (69 islolat) di antaranya memiliki genotip CTX-M. Yulianto dalam penelitian yang dilakukan di RSUD Dr. Soetomo Surabaya 27 isolat E. coli (90\%) penghasil ESBL positif mengandung gen CTX-M. hal ini menunjukkan bahwa prevalensi blaCTX-M semakin tinggi dalam menyebabkan Resistensi pada bakteri E.coli yang di berikan antibiotika sefalosporin generasi III di Indonesia terkhusus di RSUP Wahidin sudirohusodo, Makassar $(22,27)$. Tingginya prevalensi blaCTX-M dalam menyebabkan resistensi E.col terhadap antibiotika sefalosporin generasi III dihubungkan dengan fenomena "The CTX-M $\beta$-lactamase pandemic" dimana bakteri gram negatif dapat : (1) Transfer gen horizontal/transfer gen lateral dari plasmid, (2) cloning Escherichia coli (3) ESBLs yang terdapat dalam makanan (Hewan) $(25,26)$.

Penelitian harada, menemukan bahwa Isolat bakteri Escherichia coli penghasil ESBL dapat memiliki 2 atau lebih gen pembawa sifat resistensi ESBL. Adanya perbedaan dalam hasil identifikasi pada metode Double Disc Synergy Test (DDST) dan PCR (Polymerase Chain Reaction) disebabkan Eschericia coli dapat menghasilkan positif palsu dan negatif palsu, E. coli yang tidak menghasilkan ESBL, bisa menghasilkan SHV-1 secara berlebihan sehingga dapat menyebabkan tes konfirmasi positif palsu diamana Isolat- isolat tersebut terjadi peningkatan MIC ceftazidime $\geq 32$ $\mu \mathrm{g} / \mathrm{ml}$ (28.29). Beberapa penelitian mengungkapkan adanya isolat $E$. coli yang memiliki $\beta$-lactamase AmpC yang diperantarai oleh plasmind dalam penyembarannya. Dimana $E$. coli dapat memiliki dua tipe jenis enzim seperti $\beta$ lactamase AmpC dan ESBL sekaligus sehingga menyebabkan peningkatan MIC sefalosporin tetapi menghasilkan tes konfirmasi ESBL negatif palsu sehingga $\beta$-lactamase AmpC menahan hambatan oleh klavulanat (tes konfirmasi ESBL) sehingga mengaburkan efek klavulanat dan sefalosporin terhadap ESBL $(5,23)$.

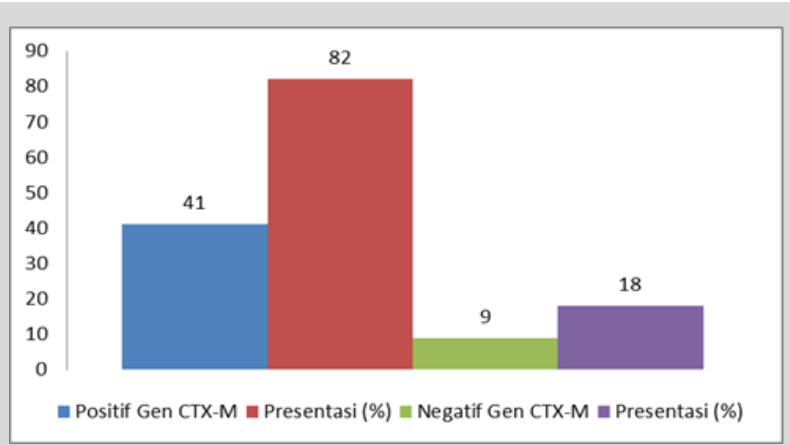

Gambar 4. Grafik Frekuensi Genotif CTX-M Penghasil ESBL E. coli pada Isolat pasien infeksi di RSUP Dr. Wahidin Sudirohusodo

\section{KESIMPULAN}

Berdasarkan hasil penelitian dapat disimpulkan bakteri Escherichia coli yang menginfeksi pasien di RSUP Dr. Wahidin sudirohusodo Makassar telah mengalami resistensi terhadap antibiotika golongan sefalosporin generasi III, sebesar $80 \%$ (40/50). Isolat Escherichia coli telah menghasilkan Extended Spectrum Beta Laktamase (ESBL) dan sebesar 82\% (41/50) memiliki gen CTX-M penghasil Extended Spectrum Beta Laktamase (ESBL).

\section{UCAPAN TERIMA KASIH}

Penulis mengucapkan terima kasih kepada LPDP Indonesia atas bantuan pendanaan. Penulis juga berterima kasih kepada Fakultas Farmasi Universitas Hasanuddin atas dukungan moril dan sarana selama penulis melakukan penelitian.

\section{DAFTAR PUSTAKA}

1. Carter GR, Wise DJ. 2004. Essential of Veterinary Bacteriology and Mycology, 6th Ed. Iowa : Blackwell Publishing.

2. Branger Catherine et. Al., 2018, Extended-spectrum $\beta$-lactamaseencoding genes are spreading on a wide range of Escherichia coli plasmids existing prior to the use of third-generation cephalosporins, Microbial Genomics 2018;

3. Bradford,P.A.(2001).Extended-spectrum beta-lactamases in the 21stcentury: characterization, epidemiology, and detection of this important resistance threat. Clin.Microbiol.Rev. 14,933951.doi:10.1128/CMR.14.4.933-951.2001

4. Gutkind, G. O., Di Conza, J., Power, P., and Radice, M. (2013). betalactamase mediated resistance: a biochemical, epidemiological and genetic overview. Curr. Pharm. Des. 19, 164-208. doi: $10.2174 / 1381612811306020164$

5. Paterson, D.L., Bonomo, R.A. 2005. Extended-Spectrum Beta-Lactamases: A Clinical Update. Clin Microbiol Rev. 18(4):657-86

6. Al-Agamy MH, Shibl AM, Tawfik AF. Prevalence and molecular characterization of extended-spectrum beta-lactamase-producing Klebsiella pneumoniae in Riyadh, Saudi Arabia. Ann Saudi Med.2009;29(4):253-7.

7. Munier GK, Johnson CL, Snyder JW, Moland ES, Hanson ND, Thomson KS 2010, Positive extended-spectrum-beta-lactamase (ESBL) screening results may be due to AmpC beta-lactamases more often than to ESBLs. $J$ Clin Microbiol. 48(2)

8. Bush K, 2010, Alarming beta lactamase-mediated resistance in multidrug resistant Enterobacteriaceae. Current Opinion in Microbiology (13). Elsevier; 558-564

9. Bonnet R., 2004, Growing group of extended-spectrum beta-lactamases: the CTX-M enzymes. Antimicrob Agents Chemother.; 48(1):1-14. 
10. Edelstein M, Pimkin M, Palagin I, Edelstein I, Stratchounski L., 2003, Prevalence and molecular epidemiology of CTX-M extendedspectrum beta-lactamase-producing Escherichia coli and Klebsiella pneumoniae in Russian hospitals. Antimicrob Agents Chemother; 47(12):3724-32

11. Wang, P., Hu, F., Xiong, Z., Ye, X., Zhu, D., et al. 2011. Susceptibility of Extended Spectrum Beta Lactamase Producing Enterobacteriaceae According to the New CLSI Breakpoints. J Clin Microbiol. 49(9):3127-31

12. Shaik, S., Fatima, J., Shakil, S., Rizvi, M.D., et al. 2015. Antibiotic Resistance and Extended Spectrum Beta-Lactamases: Types, Epidemiology and Treatment. Saudi Journal of Biological Sciences. 22, 90-101.

13. Kuper, K.M., Boles, D.M., Mohr, J.F., Wanger, A., 2009. Antimicrobial susceptibility testing: primer for clinicians. Pharmacotherapy 29 (11), 1326-1343

14. Pincus David H., 2006, Microbial Identification Using The Biomérieux Vitek ${ }^{\circledR} 2$ System, Encyclopedia of Rapid Microbiological Methods, bioMérieux, Inc. Hazelwood, MO, USA

15. Karowsky J A. et. al. 2010. Multidrug resistant urinary tract isolates of Escherichia coli : prevalence and patient demographics in the United states in 2009. Antimicrob Agents Chemother; 45(5) : 1402-06.

16. Hanna E Sidjabat, David L Paterson,. 2015, Multidrug-resistant Escherichia coli in Asia: epidemiology and management, UQ Centre for Clinical Research The University of Queensland, ISSN 1478-7210 Queensland

17. Smyth EG, O'Connell N .2004. Complicated urinary tract infection. Drugs \& Therapy Perspectives; 11(1): 63-6.

18. Prihatini, Aryati, Hetty., 2007, Identifikasi Cepat Mikroorganisme Menggunakan Alat Vitek-2 Compact, Indonesian Journal of Clinical Pathology and Medical Laboratory, Vol. 13, No. 3 : 29-132 Airlangga University Press,Surabaya

19. Kementerian Kesehatan RI. 2012. Tentang Pedoman Umum Penggunaan Antibiotika. Depkes RI : Jakarta

20. World Health Organization (WHO). 2014. Antimicrobial Resistance: Global Report on Surveillance 2014.

21. Kuntaman Kuntaman, Sanarto Santoso, Hendro Wahjono, Ni Made Mertaniasih, Endang S. Lestari, Helmia Farida, Rebriarina Hapsari, Stefani Candra Firmanti, Noorhamdani AS, Dewi Santosaningsih, Priyo
Budi Purwono, Deby Kusumaningrum, 2010, The sensitivity pattern of extended spectrum beta lactamase producing bacteria against six antibiotics that routinely used in clinical setting, Journal Indonesian Medical Association Volume: 61, Nomor: 12

22. Severin Julie"tte A., Ni Made Mertaniasih, Kuntaman Kuntaman, Endang S. Lestari, Marijam Purwanta, Nicole Lemmens-Den Toom, D. Offra Duerink, Usman Hadi, Alex van Belkum, Henri A. Verbrugh and Wil H. Goessens., 2010, Molecular characterization of extended-spectrum blactamases in clinical Escherichia coli and Klebsiella pneumoniae isolates from Surabaya, Oxford University Press on behalf of the British Society for Antimicrobial Chemotherapy, England

23. Centers for Disease Control and Prevention (CDC., 2013, U.S Department of Health and Human Services, Antibiotic Resistance Threats in The United States.

24. Brown, L., Wolf, J.M., Prados-Rosales, R. and Casadevall, A., 2015. Through the wall: extracellular vesicles in Gram-positive bacteria, mycobacteria and fungi. Nature Reviews Microbiology, 13(10), p.620.

25. Rafael Cantón, Teresa M Coque., 2006, The CTX-M $\beta$-lactamase pandemic Current Opinion in Microbiology Volume 9, Issue 5, Pages 466-475

26. Edward R. Bevan, Annie M. Jones and Peter M. Hawkey., 2017, Global epidemiology of CTX-M Beta lactamases: temporal and geographical shifts in genotype, Journal of antimicrobial chemotherapy

27. Ade Yulianto Prasetya., 2014, Pola Distribusi Gen SHV, TEM dan CTX-M pada Isolat Klinis Escherichia coli Penghasil Extended Spectrum beta lactamases (ESBLs) dari Urin Pasien di RSUD Dr. Soetomo Surabaya, Universitas Airlangga, Surabaya

28. Miro E, del Cuerpo M, Navarro F, Sabate M, Mirelis B, Prats G. 1998. Emergence of Clinical Escherichia coli Isolates with Decreased Susceptibility to Ceftazidime and Synergic Effect with Co-Amoxiclav Due to SHV-1 Hyperproduction. J. Antimicrob. Chemother. 42:535-538.

29. Rice LB, Carias LL, Hujer AM, Bonafede M, Hutton R, Hoyen C, Bonomo RA. 2000. High-level Expression of Chromosomally Encoded SHV-1 BetaLactamase and An Outer Membrane Protein Change Confer Resistance to Ceftazidime and Piperacillin Tazobactam in a Clinical Isolate of Klebsiella pneumoniae. Antimicrob. Agents Chemother. 44:362-367. 